\title{
The Literary Soundtrack: Or, F. Scott Fitzgerald's Heard and Unheard Melodies
}

\author{
T. Austin Graham
}

Anyone who writes about music is likely to have at some point been warned that words are but limited instruments for describing the most evanescent and time-bound of the arts; as the old cliché would have it, "writing about music is like dancing about architecture." A less discussed corollary to this problem is that reading about music makes for an oddly mixed experience as well. Consider, for example, the following excerpt from Richard Powers's novel The Time of Our Singing (2003), narrated by a mixed-race pianist whose artistic genealogy is at once classical and popular, traditional and modern, black and white: "Naw, naw. Play me that pretty one. The one with the string quartet.' He hummed the first three notes of 'Yesterday,' with a schmaltz three years too late or thirty too soon. I'd heard the tune thousands of times. But I'd never played it.... The problem with pop tunes was that, in those rare moments when I did recreate them at the piano, as a break from more études, I tended to embellish the chord sequences. 'Yesterday' came out half Baroque figured bass and half ballpark organ" (431). It is hard to think of many betterknown songs than "Yesterday," and upon encountering this scene, readers are quite likely to hear, somewhere in the recesses of their minds, Paul McCartney singing its "first three notes" or the sound of his accompanying "string quartet" as clearly as if a record had been put on. And yet the song has also been radically defamiliarized in Powers's treatment, still recognizable but rendered "half Baroque figured bass and half ballpark organ" by the improvising narrator. It is a counter-version of a pop song that, long before The Time of Our Singing took it up, was already among the most frequently covered in history, with Powers presenting a new "Yesterday" that his readers might be able to imagine but cannot

T. Austin Graham is a doctoral candidate at UCLA, where he is completing a dissertation on musical approaches to American literature. 
actually hear. The result is a musical-textual moment that fluctuates between the known and the unknown, the familiar and the foreign, the literally audible and the suggestively abstract.

This peculiar combination of immediacy and ambiguity is typical of an authorial device that this essay will refer to as the "literary soundtrack," defined as a series of written references to specific pieces of music that compel extra-literary responses in readers and thereby heighten, color, or otherwise comment upon the text that contains them. Over the course of the twentieth century, more and more American authors invoked music in their works to various literary effects, but precisely what are the larger stakes of a novel's reaching across aesthetic boundaries in this way? Most obviously, the literary soundtrack lends the resonance of a sister art to writers, allowing them to align two very different aesthetic forms with one another in ways more commonly associated with the stage or film. But it also cedes as much authorial control as it grants, dependent as it is on audiences to make the necessary connections between narrative and a famously slippery mode of expression. Readers, after all, hear and remember songs in different ways and in many cases have utterly divergent reactions to the same pieces of music; McCartney himself noted the mutability that his works are subject to several decades in advance of Powers, telling an interviewer, "We write songs. We know what we mean by them. But in a week someone else says something about it, says that it means that as well, and you can't deny it. Things take on millions of meanings" (Bromell 32). Readers are also as likely as not to engage in acts of musical-literary fusion intuitively; indeed, contemporary Americans have recently been argued to "think in soundtracks" because of their long exposure to popular song and musically accompanied narrative (Wojcik and Knight 1), which makes the phenomenon all the more difficult to predict or classify. Just as the soundtracked novel puts two generically distinct arts into productive dialogue, so too does it represent a fluid, Barthesian complex of authorial intention and audience participation, a musicalized work of transmission or poesis that depends to an unusual extent on reception or esthesis. ${ }^{1}$

The literary soundtrack has afforded authors a great many opportunities over the years, ${ }^{2}$ but it also poses a significant problem: what are readers to do when they encounter a literary soundtrack but are not able to hear it? Is not the novel that relies on musical recognition in any significant way also uniquely threatened by the possibility of unfamiliarity in audiences? These are especially pressing questions for those works that, like the vast majority of soundtracked novels, invoke popular music, as one of 
the defining characteristics of the popular tradition has been its dependence on and construction of tides of fashion, its unflagging emphasis on the new, and, all too often, its silencing of the old. A musical reference might resound to audiences for a time, but with the exception of a few rare cases (and "Yesterday" might turn out to be one of them), today's well-known pop song will be a relic tomorrow and, quite possibly, entirely forgotten after that. To what extent, for example, can contemporary readers listen to E. L. Doctorow's historical novel Ragtime? It has a soundtrack, but while readers may have musical reactions when Doctorow mentions an enduring classic such as Scott Joplin's "Maple Leaf Rag," it is much less likely that his allusion to "I Hear You Calling Me"-playing on a phonograph during a parlor scenewill be quite so stimulating for them $(110,160)$. This problem is still more pronounced in American novels hailing from the early twentieth century, those written by authors who took for granted that audiences would be familiar with certain music but who could not have foreseen the extent to which the Tin Pan Alley tradition would be supplanted and buried in the national consciousness. Very few of the songs mentioned in such texts ever became standards, and even those that did became much less known after the rise of rock and roll some 50 years later. As a result, a great many literary soundtracks from otherwise familiar American novels have become sequences of what would in internet parlance be called dead links, strangely inaudible musical moments that highlight the fact that entire cultural, aesthetic, and sensory dimensions of these texts have disappeared.

If a literary soundtrack depends on musical familiarity in readers and means little if it is not listened to, then it falls to scholars to do the necessary archival legwork and make audible those turn-of-the-century experiments in cross-disciplinary fusion that have since grown silent. And in the sphere of American letters, F. Scott Fitzgerald is one of the best authors with whom such musical archaeology and reengagement can begin. He was the exemplary practitioner of the literary soundtrack in the first half of the twentieth century and could perhaps even be said to have invented it in its modern form, invoking the songs of his day not just for ambiance or as subject matter but also as a means of pioneering a new, musical mode of reading and writing. A brief glance through the annotated Cambridge edition of Fitzgerald's work reveals the sheer amount of popular music in his novels and stories, not to mention the adroitness with which he uses much of it: the opening strains of This Side of Paradise (1920) faithfully reflect an idealized, prewar setting, while the most significant party song in The Great Gatsby (1925) very deliberately situates 
the plot in 1922, the annus mirabilis of literary modernism. The contemporary reader's response to these novels' soundtracks, unfortunately, is not likely to go much beyond a kind of detached appreciation, as the feelings of musical recognition and immediacy that they were intended to inspire usually elude twenty-firstcentury audiences. But Fitzgerald remains instructive even in his outmodedness. Tuneful though they may be, Fitzgerald's novels tend also to emphasize singular, time-bound, and ultimately unknowable qualities of music, thereby making his soundtracks play counterpoint to what have been identified as his central literary themes: the "sense of the passing present," the impossibility of preserving experience in a world of ceaseless change, and the value of impermanent states of being (Bruccoli 9). Fitzgerald seems to have deployed songs not just to heighten the reading act for his contemporary audiences but also to veil his novels with a certain, mysterious liminality, at once inviting readers to hear something familiar in his scenes but also underscoring the difficulty of grasping their musical meaning.

In explaining why Fitzgerald was such an innovator when it came to musical writing, one must first note that he was in many ways a product of his time, the beneficiary of various historical changes that made literary soundtracks considerably easier to construct than had been the case for most of the nineteenth century. He was of the first generation to grow up with sound recording technology and to experience its many attendant consequences as everyday realities: the widespread availability of music as a commodity, the opportunity to listen to one's favorite song at any time and in any place, the rapid expansion of the entertainment industry, the preponderance of musical fads, and the increasing importance of music as a facet of personal identity, particularly among the young. Consider the following scene from The Beautiful and Damned (1922): "In October Muriel came out for a two weeks' visit. Gloria had called her on long-distance, and Miss Kane ended the conversation characteristically by saying 'all-ll-1l righty. I'll be there with bells!' She arrived with a dozen popular songs under her arm. 'You ought to have a phonograph out here in the country,' she said, 'just a little Vic - they don't cost much. Then whenever you're lonesome you can have Caruso or Al Jolson right at your door"' (160).

Muriel's casual, tossed-off tone only highlights the momentousness of the cultural shift she embodies. Her slangy comeback, "I'll be there with bells," seems initially to allude to the old "Banbury Cross" nursery rhyme and its archaic notions of musical enticement ("With rings on her fingers and bells on her toes, she shall have music wherever she goes"). But how times have changed: 
music for Muriel is positively common, such that a song is not a sound or an event but a product that can be carried about by the handful. The jingling bells of old are being fast replaced by the bell horn of the phonograph, with Muriel pointing out-just as contemporary advertisers often did-that no one in twentieth-century America need wallow in silence or sing to oneself when the companionship of far greater and more famous musicians is both affordable and always at the ready. ${ }^{3}$ The unprecedented availability of music offers Muriel the opportunity to be the architect of her own aural environment, to harness more easily the emotionally heightening powers of a famously transitory art, and to achieve what one scholar has called the "monumentalization" of everyday life through wellchosen, mood-matching songs (Bull 181).

Fitzgerald's beloved New York City was the songwriting and performing capital of this increasingly musical America, and because he threw himself into its cultural crescendo so enthusiastically_Zelda Fitzgerald once recalled that she and her husband went to Broadway so often that they reduced their income tax accordingly (Letters 190)_one might say that he was simply in the right place at the right time, in a unique position to capture a turning point in the nation's aesthetic. No longer was a "musical" text bound to adhere to formal song structures (as in the works of Poe or the long tradition of nineteenth-century poetry set to "airs"), nor need it aim at an abstract lyricism in emulation of music's much-vaunted, "absolute" beauty (as in the formless "songs" of Whitman or in the "Decadent" verse that Fitzgerald admired in his undergraduate days). Rather, Fitzgerald could presume his audiences to be as musically up-to-date as he was, their minds so suffused with the lyrics and voices and ditties of their age that the briefest of suggestions could set them to playing in the imagination. He might not have gone so far as to argue, as has Friedrich Kittler, that technology was responsible in and of itself for such reactions, that records "turn and turn until phonographic inscriptions inscribe themselves into brain physiology" (80). But he certainly understood that the nation's culture of entertainment had grown to the extent that he could summon the unique feelings of ecstasy, humor, and pathos that he found in song with comparatively little effort in his novels, thereby yoking the associative powers of what so many nineteenth-century thinkers, from Schopenhauer to Pater, had argued was the highest of the arts. ${ }^{4}$

Popular song, it should be noted, was certainly not what music's philosophical partisans had had in mind when they afforded it such a lofty position in its relation to literature, and Fitzgerald was very much aware that his contemporaries often found something disturbing in the insidiousness with which 
America's hit tunes impinged upon the mind. Zelda Fitzgerald's autobiographical novel Save Me the Waltz (1932) would look back upon a wife who cannot keep herself from irritating her artist husband with song: "She supposed it was annoying the way the music of the day kept running through her head. There was nothing else there" (146). Sinclair Lewis, an author on whose career Fitzgerald kept careful tabs, used the word "phonograph" to denote not just a musical device but also an unthinking, clichéspouting conversationalist in his 1920 bestseller Main Street (304). And in the same year that The Beautiful and Damned appeared, T. S. Eliot's The Waste Land-much admired by Fitzgerald and a possible inspiration for his valley of ashes in The Great Gatsby-channeled a man's thoughts only to find the absurd "Shakespearean Rag" nattering away inside (41). The problem of cultural value and judgment, of course, was implicit in all this apprehension about entertainment, and some of Fitzgerald's peers found him to be less than discerning in this regard: John Dos Passos, an inveterate soundtracker himself, would later describe him as having "no taste for food or wine or painting, little ear for music except for the most rudimentary popular songs" (129). But as will become apparent, Fitzgerald's writing stakes out a middle position between fandom and detachment on the subject of entertainment, with his fiction's "rudimentary popular songs" allowing him to depict and engage with the complexities of his very busy cultural moment.

Dos Passos's verdict aside, literary scholars have been generous to Fitzgerald's supposedly tin ear over the years, with several noting an unusual aural richness in his novels and discussing their music in compelling ways. But in all previous approaches to Fitzgerald and his soundtracks, critics have been hampered by an obvious methodological problem: at no point do they give any indication that they have listened to the music he invokes or that its actual, perceptible sound is especially important in relation to literary production. Ruth Prigozy's pioneering essay on this subject is a valuable catalogue of the song titles that appear in the Fitzgerald oeuvre and a sensitive analysis of both the lyrics he quotes and the scenes he includes them in, but she treats music in almost exclusively linguistic terms and not as what it in fact is, a sonic art that unfolds in time. More recently, Mitchell Breitwieser's study of The Great Gatsby offers what is perhaps the most seductive articulation of Fitzgerald's debt to 1920s jazz and African-American musical expression, but much of his argument hinges upon an imaginary song ("Vladimir Tostoff's Jazz History of the World"), a scene that its author at one point judged to be "rotten," and an early draft of the novel that he would significantly 
revise later (Gatsby 41; Letters 92). Moreover, Breitwieser's eloquent and compelling argument leaves untouched the novel's many real and literally audible songs, very few of which are likely to strike the contemporary listener as signifying blackness in any meaningful way: Gatsby and most of Fitzgerald's other works traffic in light opera, Broadway tunes, waltzes, and novelty numbers, with even syncopation a rarity and "jazz"- at least in the form associated with the 1920s-little more than a kind of background presence, perhaps sensed by the reader but seldom able to be physically heard. ${ }^{5}$ In both cases, the problem is not so much that readers reach erroneous conclusions when they fail to listen to Fitzgerald's soundtracks; rather, it is that the aural possibilities of these musical texts are foreshortened.

What might in retrospect seem a somewhat peculiar absence in past studies of Fitzgerald's musical fiction can be explained not only by the fall from grace that his songs suffered as the decades wore on but also by the significant media obstacles that have kept scholars from being able to hear them in their original incarnations: the days of the wax cylinder and phonograph record passed along with Tin Pan Alley's golden age, with both developments helping to wither the musical familiarity that any soundtracked novel depends on. But the strides in digital music conversion and internet archiving that the turn of our own century has seen has bestowed a significant gift to scholars, with most of Fitzgerald's selected songs widely available once more and, thanks to the expiration of 1920s copyright law, free of charge. The permanent auditory record that Edison intended his technology to inaugurate has, after several decades of obsolescence, begun to be restored in a new form, and so too has the opportunity to hear Fitzgerald's texts (to say nothing of late-nineteenth- and early-twentieth-century American literature more broadly).

If Fitzgerald's soundtracks can be recovered today, what should readers now be listening for? Those who would hear his songs and retune his novels accordingly should first consider that music communicates in several ways, all of which would ideally be balanced in musical-textual analysis. Most obviously, a soundtrack can create meaning through words, and when song lyrics are quoted, implied, or otherwise used as accompaniment by authors, they can be parsed in the same way that poems are. But words are only one aspect of musical performance and listening, with a song's lyrics additionally inflected by its melody, key, rhythm, timbre, and other structural features that must be heard or imagined aurally if they are to be grasped. Finally, it does not do to think of a song merely as a self-contained aesthetic object, one whose meaning can be made entirely evident through formal explication. Over the last 20 years, musicologists have tended more and 
more to argue that music cannot be understood apart from its effects on and reception by audiences: to borrow a distinction from Christopher Small, it is "not at all a thing but an activity, something people do," an ongoing, reciprocal interaction between performers and listeners rather than a canon of autonomous works, "musicking" more than "music" (2). ${ }^{6}$ Accounting for "musicking" in a novel requires that readers think about songs in relation to literay context rather than simply on their own terms; that they ask what social roles songs play in their fictional world; and, ultimately, that they engage in the "musicking" act themselves, responding to songs and making judgments about them. Doing so depends, of course, on readers engaging in the "musicking" act themselves, responding to songs and making judgments about them. Taken together, these three methods of studying music-as language, as sound, as action-can address both its objective, semantic qualities and the subjective, variable associations it inspires. All three should therefore be brought to bear on the literary soundtrack, which is in some ways a coded message and, in others, a process to be participated in.

The experiential quality of popular song makes it hard to say at the outset just what the "correct" way of listening to Fitzgerald's fiction might be, even with the help of previously unavailable cues; the following analysis will rely on records released during the first 30 years of his life and draw conclusions accordingly, but there is no way of determining whether he was thinking of any of them while writing, to say nothing of what his early readers might have heard and reacted to. But while it is impossible, as Fitzgerald's best known character might suggest, to "repeat the past" and listen to his novels in precisely the same ways that his first audiences did, there are still significant rewards to trying, no matter how strange or distant they still might sound when all is said and done (Gatsby 86). As this essay will show, such soundtracked novels as The Beautiful and Damned and The Great Gatsby are quite musically precise, but even at their most audible they emphasize the ineffability of musical meaning as often as they ask readers to hear it. And if the literary soundtrack's at once orchestrated and amorphous legacy in the twentieth century has been any indication, Fitzgerald's invitation to musical interpretation and the act of carrying it out are every bit as important as the particular ends he might have had in mind.

Fitzgerald's first novel, This Side of Paradise, is at many points motivated by a hope that life and literature alike can be set to 
music, and its soundtrack for the most part reflects this optimism. His protagonist, Amory Blaine, frequently marvels at the ability of popular song to bring the listener and the outside world into unifying harmony, at one point writing in a love letter that "it's a wonderful night. Somebody is playing 'Love Moon' on a mandolin far across the campus, and the music seems to bring you into the window. Now he's playing 'Good-bye, Boys, I'm Through,' and how well it suits me. For I am through with everything" (82). Amory's is a familiar, quasi-Pythagorean belief in music's totalizing power: for him, songs transcend the limits of time and space, they express his thoughts and moods as well as he can himself (if not better), and above all else they are immediate and knowable. Whether Fitzgerald endorses Amory's enthusiasm or is gently satirizing it in this and other such scenes is not entirely clear. But there is no question that by 1922 and The Beautiful and Damned he had left such ideas far behind, using the popular music of his day in the service of something very different and considerably more strange.

For a sense of just how much Fitzgerald's use of the literary soundtrack did and did not change between his first and second novels, the reader should listen to the opening song of The Beautiful and Damned, a 1911 composition titled "My Beautiful Lady" (to listen to a recording of "My Beautiful Lady," go to http://cylinders.library.ucsb.edu). It is on the whole a pleasant piece, with its singer imagining what it might be like to entrance "the prettiest girls in France" with violin playing and much of its compositional structure contributing to the overall atmosphere of fantasy. Most immediately striking is the song's variation in time signatures-4/4 in its verses, 3/4 in its chorus-which has the effect of reinforcing its lyrical description of musical experience: Spencer's precisely articulated, almost fussily ornamented verses take up the hypothetical possibilities of performance, while her vocal lines during the contrasting chorus are held for longer, more languid expanses, suggesting the heightened temporality of a "sweet, sweet waltz dream" and the "rapture" that such a performance might impart. So too does "My Beautiful Lady," as interpreted by Spencer, emphasize the act of musically accompanied communication, with the pivotal lyric — "and while I'd play, my yearning eyes would say"- - turned into a vocal cadenza and the word "say" drawn out at the song's highest pitch. Ultimately, this commingling of form, content, and delivery has a self-referential quality to it, as if to suggest that the musical flights of fancy described by "My Beautiful Lady" would wind up sounding a great deal like "My Beautiful Lady" itself. Such a song would therefore not be at all out of place in the earlier, effusive pages of This Side of Paradise. 
The social context in which a song is "musicked" to, however, is as important to musical meaning as the song itself, and in The Beautiful and Damned the reader encounters "My Beautiful Lady" in an unexpected one. Here it is sung by Fitzgerald's dilettantish protagonist Anthony Patch as he luxuriates in his bathroom, admires the portraits of various Broadway actresses that he has hung on the wall, and draws some water:

"To ... you ... Beaut-if-ul la-a-dy

My ... heart ... cries_-"

He raised his voice to compete with the flood of water pouring into the tub, and as he looked at the picture of Hazel Dawn upon the wall he put an imaginary violin to his shoulder and softly caressed it with a phantom bow. Through his closed lips he made a humming noise, which he vaguely imagined resembled the sound of a violin. After a moment his hands ceased their gyrations and wandered to his shirt, which he began to unfasten. Stripped, and adopting an athletic posture like the tiger-skin man in the advertisement, he regarded himself with some satisfaction in the mirror, breaking off to dabble a tentative foot in the tub. Readjusting a faucet and indulging in a few preliminary grunts, he slid in. (22)

The striptease, the vaguely primitivist posturing, the gruntingvery little of this is likely to have been what the songwriting team of Ivan Caryll and C. M. S. McLellan had in mind as they composed the "harmonies sweet and low" of "My Beautiful Lady," and the question of whether the song is a comfortable presence or an unsettling one in this scene therefore comes to the forefront. Certainly there is nothing inherently wrong with Anthony's behavior here (let they who have never acted thus in solitude cast the first stone), but Fitzgerald's decision to enter and linger in such an intimate setting is invasive, while his explicit reference to an identifiable song invites readers to judge its appropriateness in this supremely private moment.

If readers are inclined to take the bait, they might begin by observing — as a large contingent of Fitzgerald's 1920s audience would have done-that Anthony is engaged in an act of multilayered imitation here. Most obviously, he is imagining himself as the seductive violinist described in "My Beautiful Lady," but so too is he aping the photographed Hazel Dawn: it was she who first popularized the song in the musical The Pink Lady and who brought the house down night after night with her famous 
combination of singing, dancing, and feigned violin playing. (Indeed, if her publicity photos from the period are any indication, she may even be holding a violin in the portrait that Anthony is addressing himself to.) The listening reader might also note that Anthony seems in his "musicking" to have cast himself as the song's audience as well as its performer. The main subject of "My Beautiful Lady," after all, is aesthetically induced compulsion, with its lyrics concerned primarily with creating a quasi-hypnotic state in which "ladies would forget to eat, and Pommery cease to flow." It should therefore come as no surprise that Anthony falls into a similar trance in this scene, gazing out his window after his song is through and fixing upon "a girl in a red negligé, silk surely" in a nearby apartment: "He watched her for several minutes. Something was stirred in him, something not accounted for by the warm smell of the afternoon or the triumphant vividness of red. He felt persistently that the girl was beautiful.... [F] or a not altogether explained second, posing perversely in time, his emotion had been nearer to adoration than in the deepest kiss he had ever known" (23). The musical entrancer, it would seem, has also become the musically entranced.

In many ways, then, "My Beautiful Lady" and Anthony's reaction to it can be easily explained: a young man is singing a song and experiencing the fantasy it describes. The fit between music and novel, however, is not so easy as that. The obvious disjunction between Anthony's exaggerated, masculine preening, Hazel Dawn's pinup femininity, and Elizabeth Spencer's soprano voice raises interesting gender questions, with Anthony's flexing and self-exposure seemingly in tension with the feminine persona he has taken up. (Anthony's performance becomes yet more peculiar when one considers that the song, whose singer describes how she would go about seducing other women "if I were a man," also demanded a degree of gender impersonation from Dawn, making his bathroom act an imitation of an imitation.) Additionally significant is the fact that Anthony's desire to fall under the hypnotizing power of "My Beautiful Lady" is disappointed almost immediately, with the scene's supposed correspondences between music and action shown to be illusory: upon closer inspection, he ascertains that the object of his momentary fascination in the opposite window is, in fact, "fat, full thirty-five, utterly undistinguished. Making a clicking noise with his mouth he returned to the bathroom and reparted his hair" (23). Finally, there are the still-greater questions of precisely why Fitzgerald has included this scene in his novel and whether he intends Anthony's "musicking" act to signify anything other than a passing caprice. "My Beautiful Lady" has captivated the young man, become a 
conduit for all manner of sexual fixation and cross-gendered fantasy, and clouded his perspective such that it quite literally cannot be trusted, but then the moment is over and Anthony is off to the Ritz-Carlton. The novel has presented a moment of musicalized text that, in its very strangeness, seems to demand interpretation, but it is difficult to say to what end.

Far from inspiring ecstasy or perfected emotional states, the soundtrack of The Beautiful and Damned tends to create irony, uncertainty, and puzzlement. The novel's songs and "musicking" moments raise multiple interpretive possibilities without privileging any one of them, and, on the whole, Fitzgerald seems less interested in making obvious musical statements than in asking readers to arrive at their own conclusions about what they hear. This open-endedness, moreover, frames a larger investigation on Fitzgerald's part into the relative value of popular culture and the vital-if unpredictable-role that audience reception plays in determining it. At points, the apparent randomness and incongruity of his soundtrack can seem a Menckenesque criticism of commercial entertainment's vacuity, with Fitzgerald implicitly arguing (as he would in an essay the following year) that popular culture is irrelevant at best and "the heroin of the soul" at worst (Time 139). But The Beautiful and Damned is not a purely didactic exercise, for Fitzgerald also has much in common with those writers of the 1920s who understood the popular arts to have what Gilbert Seldes called a "validity of their own," an importance that resists facile oppositions of "high" and "low" (353). This distinctive "validity" was at the time being identified in the antics of Chaplin, the new rhythms of jazz, and even, as one character in The Beautiful and Damned suggests, the frothier writings of Fitzgerald himself (347); the key to evaluating such expression lay in recognizing that popular culture was at once simpler and more complex than it was usually given credit for, that it does not always have "pretensions to art" and that audiences judge it by alternative, often idiosyncratic standards (Seldes 3). Fitzgerald's pop cultural milieu was replete with paradoxes, switchbacks, and flux, and his novel's often-inscrutable soundtrack reflects its moment in tending to force the question of just how one is to approach and 'take' commercial entertainment directly onto his listening readers.

The Beautiful and Damned evinces an unmistakable distaste for popular song at several points, but so too does Fitzgerald indicate that many of his characters have been "damned" by it only insofar as they have chosen to be: they are self-conscious about themselves and their pastimes, amused by the alleged power of music to lead them astray, and singularly unconcerned that what 
they enjoy would by a great many people be considered cultural blight. In an early section of the novel, for example, Anthony and his soon-to-be wife Gloria attend a third-rate cabaret to take in a show, and the "musicking" moment that occurs there becomes an occasion for Fitzgerald to demonstrate the perversities and surprising divergences of taste that the popular arts so often inspire. Most of the clubgoers are wretched but also know themselves to be so, pitiable largely because they decline to aspire to anything greater: they want nothing more than a place that "imitates with a sort of shoddy and mechanical wistfulness the glittering antics of the great cafés in the theater district," one that will allow them and their "giggling, over-gestured, pathetically pretentious women" to "become equally harmless, timid, and uninteresting through lack of money and imagination" (63-4). Anthony, on the other hand, cultivates an ironic superiority, allowing himself to slum in what is for him a dive and congratulating himself for having brought a woman with an "authentic distinction of face and form and manner that made her like a single flower amidst a collection of cheap bric-à-brac" (65). But he is utterly agog to hear the supposedly "authentic" Gloria murmur, "I belong here ... I'm like these people," and then go so far as to identify herself not only with her fellow patrons but also with the show that Anthony is only deigning to attend: "I'm like they are," she says, "like Japanese lanterns and crêpe paper, and the music of that orchestra" (66).

The "music of that orchestra" thus becomes a point of contention in a larger debate over cultural discernment, with the song signifying something very different to the two listeners. Fitzgerald identifies it as a novelty number titled "Ring Ting-a-Ling" by imperfectly quoting a snatch of its lyrics, and listening to Ada Jones's 1912 recording of it helps in many ways to explain why it is so important a presence in this scene (to listen to a recording of "Ring Ting-a-Ling," go to http://www.archive.org/details/AdaJones_ part1). Gloria is suited to the music, she says, because "I've got a streak of what you'd call cheapness. I don't know where I get it but it's-oh, things like this and bright colors and gaudy vulgarity" (66). Depending on one's interpretation, "Ring Ting-a-Ling" can be said to have "cheapness" and "vulgarity" as well: while it is first and foremost a paean to the telephone, its slightly ribald verses also describe men who use it as a means of fooling around behind their wives' backs (though without much success). It might additionally be interpreted as a subtle commentary on the rising volume, technological dispersal, and corresponding economic "cheapness" of music in American life, as the telephone-whose high-pitched jingling is ubiquitous in the Jones recording-allows a woman to hear music "ringing in my ear" from a great distance. 
And it seems at least possible that Fitzgerald intends the song as a reflection of his frequently nativist cultural moment and its concerns about ethnic infestation, as "Ring Ting-a-Ling" is in its literary context being performed by "a Semitic violinist" who has induced an "entrancement" in Gloria not unlike the one described in "My Beautiful Lady," making for a loaded, Svengali-esque image of control in an era whose most prominent Jews and most famous entertainers were often one and the same.

Literal-minded conclusions, however, tend to obscure rather than clarify the function of "Ring Ting-a-Ling" in this moment, as Fitzgerald seems to use it mainly to emphasize the multiplicity of reactions that popular music can inspire and to burlesque the very idea of listening for stable, "serious" meaning in commercial entertainment. The song's lyrics, if left uninflected on the page, are occasionally clever and often aspire to formal sophistication (the poetic inversion of "but for you, what would we do," for example). But Ada Jones's performance is another matter entirely, as nearly everything in the orchestration and delivery of "Ring Ting-a-Ling" leaves an impression of sheer and unconstrained goofiness. Jones's band-and presumably the "orchestra" that Gloria identifies with as well-is almost cartoonish, replete with intricate, twittering flute lines and portentous, rising brass. So too does Jones's tone of faux naughtiness, her knowing laughter, and her mock-confiding use of sprechstimme (or speech-song) transform her every word into an unmistakable joke. Moreover, when considered in a larger, "musicking" context, the humor of "Ring Ting-a-Ling" is furthered all the more by Anthony's visceral, even desperate reaction to it. Gloria's sincere attachment to the song leads him to shriek, "You're a young idiot!" (66), and his attempt at comprehending and explaining away her taste is utterly out of proportion to the silly innocuousness of the music: "Out of the deep sophistication of Anthony an understanding formed, nothing atavistic or obscure, indeed scarcely physical at all... The sheath that held her soul had assumed significance-that was all. She was a sun, radiant, growing, gathering light and storing it" (66-67). For Anthony, a fundamentally unserious song such as this is best listened to by a person capable of turning superficiality into an art form, but the irony that his theory of higher listening depends on is difficult to square with the pronounced, preexisting irony of "Ring Ting-a-Ling."

Anthony hears something like kitsch in "Ring Ting-a-Ling" and attempts to rescue his "authentic" beloved by aestheticizing her identification with it, but, according to Gloria, he has missed the point. "These people," she responds, "could appreciate me and take me for granted, and these men would fall in love with me and 
admire me, whereas the clever men I meet would just analyze me and tell me I'm this because of this or that because of that" (66). If being taken for granted is what Gloria wants, then "Ring Ting-a-Ling" no doubt appeals to her precisely because it is so happily and unapologetically vacant. Even the song's most inquisitive, searching lyrics-"I would give the world to know half the things you hear"- - ultimately circle back to nothing more than the telephone itself, with most of its cheerfully rendered conversations centered around such banalities as getting numbers right, returning calls, describing where people are and what they do while they talk, and most importantly hearing a "ring ting-a-ling" to respond to. Indeed, the song's fixation on the sound of the telephone causes it at times to veer towards utter nonsense, with Jones lapsing into a gabby but ultimately anti-expressive babble in promising that "If you don't ring-a-ling, ting-a-ling-a-ling-a-ling / Then I'll ring-a-ting-a-ling for you" at the end of each verse. The medium is the only message here: Gloria is attracted to meaningless signification in her music, in her fellow nightclubbers, and in herself, and nothing could be more beside the point than a pretentious, intellectual search for content in the song or the woman.

Where Anthony listens for "significance," Gloria deliberately avoids it, and in the process she bypasses the familiar binaries of high and low culture that her partner relies on. Fitzgerald is often credited with having revealed the hollowness of America's gaudy and hedonistic boom years, but here one of his own characters has beaten him to the punch and gone so far as to argue that such hollowness is in fact something to be enjoyed and wished for. Gloria's perspective on popular culture would seem, moreover, to preempt and invalidate any criticisms that the mocking Anthonys, highbrow Menckens, or paranoid Adornos of her era might have to offer about popular culture and its consumers: it makes little sense, after all, to expose or attempt to correct someone's bad taste when she is aware of and happy to have it. As Gloria seems to be putting it, much of the fun of pop music lies in listening to the "wrong" songs rather than the "right" ones, in having proud, even defiantly shabby cultural predilections. "Ring Ting-a-Ling" is both a good song and a bad one by her standards, its value bound up in its apparent lack thereof. And thus does this scene flirt with the debasing qualities of entertainment only to theorize a jolly variety of musical nihilism, a pleasure to be had in cultural aporia that pervades The Beautiful and Damned and that Fitzgerald's soundtrack helps sustain through its frequent dares to find larger meanings in songs where there may not (or ought not) be any.

It is this feeling of uncertainty and this unanswered question of what, if anything, popular music ultimately signifies that most 
distinguishes Fitzgerald's soundtracked novel from the many, nonliterary media of the period that also aligned narrative and song in atypical or subversive ways. Musical disconnection had been common in the dramatic arts for years before The Beautiful and Damned, but it was usually much more obvious in its communication. Nineteenth-century stage productions often featured interludes between their acts that had as little relation to their larger plots as possible, so as to leave the impression that their audiences were getting their money's worth of varied entertainment. Silent film, meanwhile, had made musical-visual dissonance an everyday trope by 1922, much of it derived from the so-called "funning" that accompanists would indulge in by introducing humorously incongruous songs at key narrative moments. ${ }^{7}$ While "funning" necessarily fell out of favor as cinema marched towards synchronization in the late 1920s, it could still be heard from time to time in those films, stage works, and novels that used music to create sarcastic, even gruesome negative reinforcement: think, for example, of Theodore Dreiser's decision to have Roberta Alden sing "Oh, the sun shines bright in my old Kentucky home" just before she drowns in his 1925 novel An American Tragedy (521), or the unforgettable alignment of James Cagney's corpse and the jolly recording of "I'm Forever Blowing Bubbles" in the final scene of The Public Enemy (1931). ${ }^{8}$ By the time that The Beautiful and Damned appeared, then, American audiences had grown accustomed to narratives that, as though thumbing their noses at the idea of a unified, Wagnerian gesamtkunstwerk, existed in states of cross-aesthetic tension and demanded to be evaluated with varying degrees of irony.

As the years went by, Fitzgerald became more and more adept at cinematic "funning," honing his ability to create arresting, bitingly subversive contrasts between song and narrative. (This technique is especially evident in the many scenes of matrimonial despair in Tender Is the Night [1934] that Fitzgerald punctuates with perky favorites from Dick and Nicole Diver's youth. ${ }^{9}$ ) But more innovative was the musical uncertainty, anxiety, and eeriness that he was able to conjure in The Beautiful and Damned, whose soundtrack creates obvious aesthetic disconnections but seldom does so in the service of either humor or horror in their most obvious forms. ${ }^{10}$ Indeed, the novel seems most modern in its willingness to play as many sides of the field as possible, inviting its readers both to identify with and condemn its frivolous consumers, to take pleasure in popular song even as they denigrate it, and, above all else, to find its musically inflected scenes simultaneously amusing and off-putting. As in the case of Anthony, Gloria, and "Ring Ting-a-Ling," readers who can hear Fitzgerald's soundtrack 
[R]eaders who can hear Fitzgerald's soundtrack are frequently asked to entertain more than one interpretation of its narrative significance, and the range of conclusions that they might reach can have profound implications for the novel's larger commentary[.] are frequently asked to entertain more than one interpretation of its narrative significance, and the range of conclusions that they might reach can have profound implications for the novel's larger commentary-especially if they decline to settle on any definitive ones.

Perhaps nowhere is the tuneful paradox of The Beautiful and Damned more audible than in its "Broken Lute" section, an attempt on Fitzgerald's part to write in scripted, dramatic form that has, as its title might indicate, a marked dissonance to it. Taken as a whole, the chapter reads as a quasi-musical comedy with a disorienting twist, accompanied by a soundtrack that is both humorously apropos and utterly cringe-inducing. The music in question is "Poor Butterfly" (a song so inescapable in its day that it inspired a threatening response titled "If I Catch the Guy Who Wrote Poor Butterfly"), the occasion for it is a house party, and the "musicking" act is performed by Anthony and his friends as they listen to a record and get dangerously intoxicated. "Poor Butterfly" begins to play alongside one inebriate toasting "the defeat of democracy and the fall of Christianity" over a round of shots (229), and listening to Elizabeth Spencer's 1917 recording of the song should give readers a better sense of this remarkable, deeply unsettled, and too often unheard literary moment (to listen to a recording of "Poor Butterfly," go to http://cylinders.library. ucsb.edu).

Considered on its own, "Poor Butterfly" is uncomfortably arrayed against itself. Its adaptation of Puccini's well-worn tale of pining love, cultural submission, and suicide might read as melancholy on the page, but Spencer's frequently upbeat, even sprightly delivery of Butterfly's story winds up sounding either childishly naïve or appallingly inappropriate. The musical flippancy with which this tragedy is presented grows still more perverse in Fitzgerald's literary context, as his stage directions indicate that Anthony and his friends are merrily singing along with the record: it takes but little imagination to hear a company of drunks imitating Spencer's forced dialect and bellowing, at the song's extraordinarily operatic high point, that Butterfly has learned "to love with her soul" thanks to her having been exposed to "the "Merican way." Fitzgerald was not always sensitive when he attended to race matters in his fiction, but in many ways he seems here to be condemning the song's cultural ideology and tarring his characters with it. Particularly repulsive are the ways in which his revelers make the song's chauvinism explicit in their own behavior, with one rousing Anthony's butler-significantly, a Japanese man named Tana-from his sleep and commanding him to accompany "Poor Butterfly" on flute. There is unmistakable cruelty in this increasingly surreal scene as Tana is placed atop a precariously 
balanced pile of furniture and made to add ethnic flavor to the song's exercise in exoticism, leaving the impression that Anthony and his circle are modern equivalents of Puccini's callous Pinkerton. Thus, as the reader listens to the generically Oriental melodies of Spencer's record intertwining with the imagined sound of Tana's compulsory flute, the musical moment becomes, in the words of Fitzgerald's stage directions, "one of those incidents in which life seems set upon the passionate imitation of the lowest forms of literature" (230).

But if Fitzgerald intended to use "Poor Butterfly" as a means of casting his characters and the popular culture they enjoy in an exclusively unflattering light, then he failed for a simple reason: his scene and his musical selection are also quite funny, if not to the characters who actually experience them. Butterfly's story of bereavement and loss, so out of place in an often-peppy song and at a delirious party, turns out to be strangely appropriate when Anthony's grandfather, Adam Patch, appears suddenly in the room, his approach "rendered inaudible by the pandemonium" (230). Now Fitzgerald has entered the world of stock characters and theatrical cliché, for Adam Patch is significant primarily for being old, deeply conservative, and in control of Anthony's allowance-the last person in the world, of course, who ought to have stumbled upon such an affair. The elder Patch's timing is perfect in that it is so utterly imperfect, and it is a clever touch on Fitzgerald's part to have him arrive in the middle of a song whose protagonist yearns to be reunited with her distant, "fine young American from the sea." The song's Butterfly figure lives only for the moment when her lover will "come to me" and she will feel his embrace once more, but while she will presumably never enjoy such an experience, one of Anthony's out-of-control guests comes close: he "begins to spin round and round, more and more dizzily-he staggers, recovers, staggers again and then falls in the direction of the hall...almost into the arms of old ADAM РАтсн" (230). As the phonograph sings of Butterfly's lovelorn hopes they are consummated by others in a supremely awkward manner, and with the near-collision comes a literary iteration of one of the all-time favorite "takes" of stage and film history: "the phonograph gags," the music grinds to a halt, and the party is left in silence, "weighted with intolerably contagious apprehension" (230). And thus does "The Broken Lute" become musical-literary slapstick: the dour, wealthy grandfather has dropped in not just at a bad time but at the worst possible one, a famous, melodramatic love scene has been burlesqued with undertones of homosexual panic, and an initially out-of-place song is revealed to be utterly, if grotesquely, appropriate. 
The extraordinary quality of this scene is its musical equivocality, its uneasy combination of pitch-perfect comedic timing and deathly serious importance to the novel's larger narrative. Read one way, it is probably the best bit of dramatic writing Fitzgerald ever produced, certainly funnier than anything he came up with in The Vegetable; or, From President to Postman (1923)—his first and only proper play-and it works as well as it does because it is so hackneyed. ${ }^{11}$ But if the incongruous "Poor Butterfly" makes such a scene all the more outlandish and humorous, it also, thanks to its racial insensitivity and its grim implication of mortality, casts a shadow that becomes more and more dark as Fitzgerald's narrative progresses. Adam Patch leaves the scene, writes his grandson out of his will, and dies three months later, and while in a Broadway musical such a development might kick off a series of madcap adventures (misplaced wills abound in the then-popular productions of George M. Cohan), here Anthony and Gloria sue for their inheritance and grow increasingly impoverished, addicted, and self-abasing as the court case drags out. When a judge finally rules in their favor, the sordidness of the "Poor Butterfly" affair and the morbidity lurking within the oddly upbeat song only grow more apparent: in the novel's last chapter, Fitzgerald reveals that Edward Shuttleworth - the assistant who escorted Adam Patch to the fateful party and who once managed the family fortune-has shot himself dead in a Butterfly-like state of despair. The memorable music, if it is recalled at novel's end, therefore comes to linger in both amusing and deeply ominous ways, with Fitzgerald, a writer capable of simultaneously nailing and deflating pop conventions, aiming not to make readers laugh or blanch at "Poor Butterfly" but rather to do both, somewhat nervously, at once.

In this scene and elsewhere, the power of Fitzgerald's soundtrack lies in its uncertainty, with readers of The Beautiful and Damned invited to experience quite literally the cultural flux that Fitzgerald's characters must negotiate and to wrestle with the enigmatic musical commentary of an author who, as critics from Edmund Wilson to D. G. Kehl have observed, seems often to have drawn his comedy and his tragedy from the same sources. ${ }^{12}$ At a historical moment when it was becoming increasingly common, even expected for writers to weigh in on popular culture, Fitzgerald was one of the few to conclude contra the aloof satire of Lewis and the condemnation of Mencken that its literary merits often lay in its very badness, that one's attitude towards it could not but be one of constant and often paradoxical readjustment. His soundtrack, meanwhile, raises as many questions as it answers in its relation to his narrative, provoking listeners with simultaneous cheer, bitterness, and irrelevance and seeming to suggest, in the 
words of one of Fitzgerald's more famous epigrams, that those who would contend with popular song must possess "the ability to hold two opposed ideas in the mind at the same time, and still retain the ability to function" (City 139). And if Anthony's unenviable, catatonic end in the novel's final pages is any indication, the constant position-taking that such a crowded culture and musical environment demand are almost enough to drive one mad.

The question of how well music ever "fits" personal experience or the narratives that contain it would hang over the rest of Fitzgerald's novels, and most of the time he seems to have reached rather disappointed conclusions. The soundtracks of his later works tend towards either the flatly depressing or the absurd: Dick Diver's favorite songs inspire torturous memories in Tender Is the Night, while the soprano of The Love of the Last Tycoon (1941) who sings a single lyric-“Come! Come! I love you only"-over and over again into a studio microphone seems positively mad, given that she is doing so in the middle of a jolting Southern California earthquake (21). The Great Gatsby, however, strikes a unique balance between harmony and dissonance, one that is particularly worth bearing in mind for the reader who would consider the larger problem of listening to long-outmoded but still audible musical literature. It presents a protagonist who seems determined, as Hugh Kenner has put it, to create a milieu in which "even when the words are wrong the music is right" (42), with Gatsby's songs of courtship and nostalgia—-"The Love Nest," "Ain't We Got Fun," "Beale Street Blues"- - seeming in many ways to be perfectly suited to the scenes, people, and actions they accompany. But so too does this novel's soundtrack point to music's inevitable sense of liminality, illustrating the impossibility of sustained, harmonious experience and reinforcing the sense of being out of tune that pervades so many of Fitzgerald's works.

On the one hand, the beguiling sound of music in The Great Gatsby involves the reader all the more intimately with Fitzgerald's ongoing search for what Milton Sterne has called the "golden moment" in his fiction, the achievement of a state of being so cosmic that it represents nothing less than a "release from the condition of time itself" (57). But on the other, Fitzgerald's soundtrack seems to indicate that musically inspired emotions are perfect only insofar as they are temporary and fleeting, escaping listeners even as they are possessed of them. Throughout his early writings, Fitzgerald shows himself practically to have been a born 
believer in the Keatsian, dialectical notion that death is the mother of beauty, that moments of intense feeling are most poignant when just about to be extinguished. At the ancient age of 22, he was already declaring, "God! How I miss my youth" in his letters (18), and at the start of his publishing career, he observed through Amory Blaine that "the sentimental person thinks things will last-the romantic person has a desperate confidence that they won't" (Paradise 212). But it was in The Great Gatsby-and in particular its handful of musical scenes-that he was able to express this amalgamation of happy melancholy and exquisite defeat most deftly, with his literary soundtrack allowing readers to share in the unique pleasure of fading emotion and possibility. Most importantly of all, his soundtrack retains its ability to do this not in spite of but because of the fact that, as the years go by, it grows more and more unfamiliar. Whereas This Side of Paradise and The Beautiful and Damned tend to suffer when they lose their musical immediacy, The Great Gatsby seems in many ways to triumph all the more by its diminuendo.

Consumed in The Great Gatsby with the futility of attempting either to hold on to present moments or to repeat the past, Fitzgerald made his soundtrack something new and, from a twenty-first-century view, quite influential for the American writers who followed him: a musical accompaniment that can be heard clearly but that grows more compelling as it becomes less audible. The final party at Gatsby's mansion is perhaps the best example of Fitzgerald's peculiarly explicit and distant melodiousness, one of the narrative's emotional breaking points and an illustration that its soundtrack can never be anything more than an echo of what it once was, in spite of the fact that readers can hear it with an unusual degree of specificity. A certain discord, a "pervading harshness," has settled upon the tense scene, but then Daisy Buchanan begins to sing, adding to the party's background music "a husky, rhythmic whisper, bringing out a meaning in each word that it had never had before and would never have again.... Each change tipped out a little of her warm human magic upon the air" $(81,84)$. In some ways this is vintage Fitzgerald, a fleeting experience that cannot be repeated or even adequately described in words, one whose vitality fades at the very moment it becomes apparent. But it is not so ephemeral as that, for Fitzgerald also names the song that Daisy has performed, "a neat sad little waltz of that year" called "Three O'clock in the Morning" (85). This inspires musing from Nick Carraway: "What was it up there in the song that seemed to be calling her back inside? What would happen now in the dim incalculable hours?" (85). By way of finding out, the reader is encouraged to listen to the 1922 
recording of "Three O'clock in the Morning" by the accomplished classical singer and pop recording artist John McCormack (to listen to a recording of "Three O'clock in the Morning," go http:// www.archive.org/details/JohnMcCormack).

Those who have never heard this song before are likely at first to feel somewhat cheated by it. Nick's uncertainty as to why "Three O'clock in the Morning" calls his cousin back to Gatsby seems positively inexplicable after its lyrics have been consulted, as their preoccupation with courtship makes for painfully direct commentary on this scene. So too does the song seem to find its own meaning to be utterly self-evident, enacting a kind of musical tautology by describing itself as a "melody so entrancing" and imagining that everything in the external world-whether a dancer's heart "beating in time" or an orchestra's ding-dong imitation of the Cambridge Quarters-moves to its 3/4 rhythm; to hear the song is automatically to understand its significance. But perhaps most striking of all is the grandiosity of "Three O'clock in the Morning," whose melody is comprised of heroic arpeggios, the occasional acrobatic leap (the words "be" and "dawning" are more than an octave apart), and other flamboyant touches that would be almost as appropriate in a circus as in Fitzgerald's dreamy setting. By the time McCormack delivers his full-throated, chivalric plea"say that there soon will be a honeymoon"- - the song has come in many ways to seem too flashy, too extravagant, and, above all else, too literal for what is otherwise a brooding and ambiguous scene.

To a degree, Fitzgerald's soundtrack undercuts the emotional importance of this moment, leaving Daisy in the thrall of a rather obvious song and rendering Nick somewhat daft for not understanding why she appears to enjoy it. Nor is there much reason to suppose that Fitzgerald's audience would have been any more forgiving than modern ones of such a cliché: the musicians who accompanied the silent films of his day were often warned not just against performing songs that seemed out of place in the larger story but also against ones that, like "Three O'clock in the Morning," were excessively obvious fits (Lastra 112-3). Music can distract from narrative even if it is in perfect synchronization with it, disappointing those audience members who might have expected something more creative or oblique. Reading this scene in conjunction with listening to McCormack's performance, then, can serve to rob Daisy's singing of its mystery, no doubt leading some readers to decry, as did a sour William Butler Yeats after himself attending a John McCormack concert in 1924, "the clarity of the words ... the damnable clarity of the words." 13

For quite some time, scholarship on Fitzgerald tended to keep a certain embarrassed silence about these and other topical 
aspects of his fiction (the slang, the fads, the celebrities), concentrating instead on what were thought to be his timeless or universal themes for much the same reason that listeners are likely to recoil from "Three O'clock in the Morning"- the cultural detritus that Fitzgerald chose to immortalize in his fiction long after it ceased to be in vogue can seem too slight, far from commensurate to the reader's capacity for wonder. But the fascinating quality of this song, and so much of the music permeating The Great Gatsby, is the extent to which its questionable, even dubious aesthetic worth is also the very thing that highlights Fitzgerald's almost transcendental sensitivity to what Emerson called the "evanescence and lubricity" of experience, his determination to record his impressions as they drifted away from him (473). Even when it seems so harmonious as to be almost hackneyed, music makes Fitzgerald's point by negative rather than positive example, in this scene rendering Daisy increasingly unknowable even as it seems to lay bare her mood and mind, pulling readers into her performance at the same time that Fitzgerald points toward something in it that defies description. Just as one of Fitzgerald's great triumphs was to create in Gatsby a protagonist who is as "blurred and patchy" at novel's end as he was at the beginning in spite of all that has been revealed about him (Letters 126), so too does the simultaneously audible and resistant presence of "Three O'clock in the Morning" draw attention to an aspect of performance that cannot be understood except in its moment of creation, leaving readers all the more curious as to how Daisy transformed so straightforward and unexceptional a ditty into something that, at least to its witness, was brimming with life.

The irony is that Fitzgerald could only have achieved these and other such effects in this novel with the much-abused mass entertainment of his day. As is the case with his allusions to pop cultural icons like the Broadway star Gilda Gray, the bestselling novel Simon Called Peter (1922), and the scandalous Chicago "Black Sox," a song like "Three O'clock in the Morning" anchors Fitzgerald's mythic, imagined world in a specifically dated, eminently recognizable setting, reinforcing the novel's signature contrast of Platonic conception and persistent actuality. And no other variety of music would have allowed him so successfully to heed Conrad's famous call-which Fitzgerald named as a particular inspiration in his preface to the 1934 reprinting of The Great Gatsby-for a literature able "to make you hear, to make you feel" with palpable, physical intensity. ${ }^{14}$ There is, of course, a great deal of vaguely described "yellow cocktail music" and other such aural abstraction in this text (34), but only a widely known song, one inextricably tied to its time and place and hopelessly dependent on 
the whims of fashion, can tantalize the reader with the sense that some crucial impression or revelation is near, as close as the melody of a famous and catchy tune, and yet also growing further out of reach with each passing year. Readers who are able to hear "Three O'clock in the Morning" are thus obliged to share in the feelings of belatedness that haunt Fitzgerald's novel, listening to the music that pervaded some of the most familiar scenes in American literature but left to conclude that they have missed something, that a crucial meaning has gone out of the songs.

Therein lies the larger problem for the critic or reader of soundtracked literature from ages past: it is not easy "to music" to something that one must go to great lengths to hear at all, and those songs that can be recovered can seldom be listened to on the terms that they once were. Many of the old literary soundtracks are now available in ways unthinkable even 20 years ago, but delving into them often serves to illustrate just how remote so much of America's music has become and how unlikely it ever is to be otherwise. The novelty numbers can be too absurd, the sentimentality too extreme, the delivery too affected, the miserable state of production too grating on the ear. When resurrected such music can alienate audiences as much as interest them, making it difficult to imagine that the literary works that depend on it can be enlivened in any significant way by close listening. But in many of the most effectively soundtracked novels of the last 100 years, this difficulty often turns out to be less an obstacle than the very point of writing about music in the first place. Returning to Powers and The Time of Our Singing, one finds that the problem of capturing a time-bound art-whether on a record or on the page-is no closer to being resolved in a new millennium of unprecedented inscription. Remembering a concert from his youth, Powers's narrator observes the following: "I will look for this group throughout my life-on vinyl, then tape, then laser pit. I'll go to performances in hope of resurrection and come away empty. I'll search for these singers my whole life, and never come any closer than suspect memory.... I could look all the singers up: Every year we pass through is hidden away, if not in a cloistered scriptorium somewhere, then in a bank of steel filing cabinets and silicon chips. But everything I'd find would only kill that day. For what I thought I heard that day, there are no names. Who knows how good those singers really were? For me, they filled the sky" (160). Now as then, the soundtracked novel maintains a fundamental tension between the archival and the evanescent, between the physical traces of the past and the futility of attempting to experience it in the present. Its music, when unfamiliar, ought not to be left cultural white noise when it is possible to make it audible, but neither can its recapitulation be assumed to 
bring a missing completeness to a text. Ever frozen in time and mechanically repeatable, such music and such literature cannot but be heard anew on each encounter.

\section{Appendix: Lyrics for Fitzgerald's Soundtracks}

In transcribing these lyrics I have made some minor editorial changes, altering punctuation and capitalization where necessary to make for easier reading. The words below, however, will not always match those heard on the provided recordings, as singers have in many cases used alternate phrasings and verses. Particularly interested readers and listeners are invited to consult the online sheet music archives provided by Indiana University, available at http:// www.letrs.indiana.edu/s/sheetmusic/; the University of Colorado at Boulder, available at http://ucblibraries.colorado.edu/music/smp/ index.htm; and the Library of Congress, available at http:// www.loc.gov/performingarts/. Scanned facsimiles of each song listed can be found on these websites, with all three representing valuable aids to study.

\section{My Beautiful Lady}

Composed by Ivan Caryll, lyrics by C. M. S. McLellan. New York: Chappell \& Co., Ltd., 1911.

If I were a man I'd be not president, but just he

Who plays the violin in the band, at the Café de Paris.

For then I should have a chance, by fiddling to entrance,

And fill with ardor of romance the prettiest girls in France.

And while I'd play

My yearning eyes would say, my yearning eyes would say,

To you, beautiful lady, I raise my eyes,

My heart, beautiful lady, to your heart sighs,

Come, come, beautiful lady, to Paradise

E're the sweet, sweet waltz dream dies.

Glide, Glide, beautiful lady, on light, bright wings,

While the rapture of music around us swings,

Dream, dream, dream and forget care, pain, useless regret, Love, love, beautiful lady, in my heart sings.

Each night on a rippling tide of melody I would glide, And live in the light of beauty's eyes, with ev'ry thing else outside. 
I'd woo with a magic bow, such harmonies sweet and low, The ladies would forget to eat, and Pommery cease to flow.

Ring, Ting-A-Ling

Composed by Jean Schwartz, lyrics by Jerome William.

New York: Jerome \& Schwartz, 1912.

Oh you little telephone, you're a perfect dear,

I would give the world to know, half the things you hear;

When the cook needs something quick on you we depend

And but for you what would we do? You're more than just a friend.

We love your welcome call, you've made the world seem small,

Ring-ting-a-ling-ting-a-ling on the telephone and ring me up tonight,

Ring-ting-a-ling-ting-a-ling on the telephone, You've got my number right

(Oh, hello)

Ring-ting-a-ling-ting-a-ling on the telephone, and send a kiss or two

If you don't ring-a-ling, ting-a-ling-a-ling-a-ling,

Then I'll ring-a-ting-a-ling for you.

Jones went to the Waldorf once with a friend to dine,

Not a man, a lady friend, that knew a friend of mine;

Rang his little wifey up, Can't get home my dear

'Till very late, so don't you wait, I've pressing bus'ness here.

But darling little frau, said, dear, where are you now?

Ring-ting-a-ling-ting-a-ling on the telephone, I'm in my office dear,

Ring-ting-a-ling-ting-a-ling I hear music love, It's ringing in my ear

(And singing)

Ring-ting-a-ling-ting-a-ling on the telephone, I hear corks popping too,

If you don't ring-a-ling, ting-a-ling-a-ling-a-ling,

Then I'll ring-a-ting-a-ling for you.

It's a very handy thing, when you want to shop,

Once you get the habit good, my, it's hard to stop;

Though it really doesn't quite always tell the truth.

Uneasy lies the head that lies, inside the little booth. 
Each little telephone, has meanings of its own.

Ring-ting-a-ling-ting-a-ling on the telephone, Is that you, Louie Brown?

Ring-ting-a-ling-ting-a-ling on the telephone, My wife's gone out of town,

(Large ev'ning)

Ring-ting-a-ling-ting-a-ling on the telephone, Come join our midnight crew

If you don't ring-a-ling, ting-a-ling-a-ling-a-ling,

Then I'll ring-a-ting-a-ling for you.

Poor Butterfly

Composed by Raymond Hubbell, lyrics by John L. Golden.

New York: T. B. Harms \& Francis, Day \& Hunter, 1916.

There's a story told of a little Japanese

Sitting demurely 'neath the cherry blossom trees.

Miss Butterfly her name.

A sweet little innocent child was she,

Till a fine young American from the sea,

To her garden came.

They met 'neath the cherry blossoms ev'ry day

And he taught her how to love in the 'Merican way,

To love with her soul! 'twas easy to learn;

Then he sailed away with a promise to return.

Poor Butterfly! 'neath the blossoms waiting

Poor Butterfly! For she loved him so.

The moments pass into hours, the hours pass into years

And as she smiles though her tears, she murmurs low,

The moon and I know that he be faithful,

I'm sure he come to me bye and bye.

But if he don't come back, then I never sigh or cry

I just mus' die. Poor Butterfly.

Won't you tell my love she would whisper to the breeze

Tell him I'm waiting 'neath the cherry blossom trees.

My Sailor man to see.

The bees and the humming birds say they guess,

Ev'ry day that passes makes one day less.

'Till you'll come to me.

For once Butterfly she gives her heart away,

She can never love again she is his for aye,

Through all of this world, For ages to come, 
So her face just smiles, tho' her heart is growing numb.

Three O'clock in the Morning

Composed by Julian Robledo, lyrics by Dorothy Terriss.

London: West's Limited, 1921.

It's three o'clock in the morning,

We've danced the whole night thru, And daylight soon will be dawning, Just one more waltz with you.

That melody so entrancing

Seems to be made for us two,

I could just keep right on dancing

Forever dear with you.

There goes the three o'clock chime,

Chiming, rhyming,

My heart keeps beating in time,

Sounds like an old sweet love tune

Say that there soon will be

A honeymoon.

\section{Notes}

1. See Roland Barthes's famous formulation of the "writerly text," an ongoing, collaborative interplay between text and audience-a "production without product"-in which meaning is constructed by, rather than simply communicated to, the reading individual (5). For a sustained meditation on the question of what role the aural sense plays in the reader-text relationship, see Garrett Stewart, Reading Voices: Literature and the Phonotext (1990).

2. Indeed, there are entire subgenres of fiction that would be difficult to imagine without it, such as the contemporary rock n' roll novel (including such titles as Roddy Doyle's The Commitments [1987], Nick Hornby's High Fidelity [1995], Salman Rushdie's The Ground Beneath Her Feet [1999], Jonathan Lethem's You Don't Love Me Yet [2007], Zachary Lazar's Sway [2008], and Arthur Phillip's The Song Is You [2009], to name but a few). This is not to say, however, that a rock novel presupposes an audible soundtrack: most of the songs referred to in Don DeLillo's Great Jones Street (1974)—with the notable exception of "Good King Wenceslas"—are decidedly fictional.

3. Studies of the phonograph and its effects on musical practice are legion. See Greg Milner, Perfecting Sound Forever: An Aural History of Recorded Music (2009); David Suisman, Selling Sounds: The Commercial Revolution in American Music (2009); Mark Katz, Capturing Sound: How Technology Has Changed Music (2004); William Howland Kenney, Recorded Music in American Life: The 
Phonograph and Popular Memory, 1890-1945 (1999); and Michael Chanan, Repeated Takes: A Short History of Recording and its Effect on Music (1995). For one of the more famous meditations on music's alleged degradation in the mass market and its twentieth-century status as a collectible object, see Jacques Attali, Noise: The Political Economy of Music $(1977,1985)$.

4. While there is little indication that Fitzgerald ever read W. E. B. DuBois, he seems to have been aiming at a pop-based literary effect not unlike the race-specific one that had lent The Souls of Black Folk (1903) —with its many juxtapositions of text and "sorrow songs" - such power some 20 years earlier: for all their obvious differences, both authors seem to have been attempting to stir those readerly emotions that music reaches with unique immediacy and to redirect them into their texts. Moreover, each would seem to confirm recent critical studies of modernism that characterize that movement as fundamentally interdisciplinary in character and particularly concerned with stimulating direct, bodily sensations in readers. See Daniel Albright, Untwisting the Serpent: Modernism in Music, Literature, and Other Arts (2000); Tim Armstrong, Modernism, Technology, and the Body: A Cultural Study (1998); and Sara Danius, The Senses of Modernism: Technology, Perception, and Aesthetics (2002). For a discussion of DuBois and the "sorrow songs," see Eric J. Sundquist, To Wake the Nations: Race in the Making of American Literature (1993).

5. It should be noted that the figure of "Vladimir Tostoff" is often argued to have a real-world analogue in the so-called "King of Jazz" of the 1920s, the bandleader Paul Whiteman. For an interesting discussion of race and the presumption of blackness as it relates to early-twentieth-century "jazz literature," see Ryan Jerving, who argues for an expansion of the term that would account for the "whiteness" of Fitzgerald's music; Jerving's argument is to be found in "Early Jazz Literature (And Why You Didn't Know)," American Literary History 16.4 (2004): 648-74. For more on Fitzgerald and jazz, see also Gerald Early, "The Lives of Jazz," American Literary History 5.1 (1993): 129-46.

6. In addition to Small, other useful theorizations of the role audiences play in the construction of meaning in popular music include Simon Frith, Performing Rites: On the Value of Popular Music (1996); Brian Longhurst, Popular Music and Society (1995); and Keith Negus, Popular Music in Theory: An Introduction (1996).

7. For more on the history of asynchronous soundtracking in turn-of-the-century film and theater, see Rick Altman, Silent Film Sound (2004); James Lastra, Sound Technology and the American Cinema: Perception, Representation, Modernity (2000); and David Mayer and Helen Day-Mayer, "A 'Secondary Action' or Musical Highlight? Melodic Interludes in Early Film Melodrama Reconsidered," in The Sounds of Early Cinema (2001).

8. This practice on the part of authors as well as filmmakers serves to confirm Michel Chion's sense that the "juxtaposition of scene with indifferent music has the effect not of freezing emotion but rather of intensifying it" (8).

9. There is a great deal of "funning" in Fitzgerald's stories, as well. For two particularly good examples of action juxtaposed with music at its most obviously inappropriate, see "Three Acts of Music" (1936) in The Lost Decade: Short Stories from Esquire, 1936-1941 (2008) and "That Kind of Party" (1937) in The Basil and Josephine Stories (1973). 
10. In this, Fitzgerald might be profitably compared with those modernists of film and opera who felt that the creation of discontinuity across the arts and senses could be an aesthetic end in and of itself rather than merely a means of disrupting and, in so doing, enlivening linear narrative. Perhaps the most obvious counterpart to Fitzgerald's musical experimentalism is Sergei Eisenstein's 1928 "Statement" on sound recording technology, which argued for the "contrapuntal" relation of visuality and aurality in the avant-garde cinema and against the clearer, easily explained varieties of synchronicity and asynchronicity that characterize most film today. See Eisenstein, Film Form: Essays in Film Theory (1949). For an overview of other instances of musical asynchronicity in modernism across the arts, see Albright.

11. George Jean Nathan, the famously demanding theater critic to whom The Beautiful and Damned is dedicated, might as well have been describing the "Poor Butterfly" scene when he dryly observed some years before that, on the oftenconventional musical stage, it is all but guaranteed that "when a character observes: 'When I see that fellow So-and-So again, you bet I'll tell him what I think of him!' the character must presently turn around, see that the man against whom he has just lodged the threat has been standing there all the while, and, beholding him, must slink meekly away" (35).

12. See Edmund Wilson, "F. Scott Fitzgerald" (1922), Rpt. in F. Scott Fitzgerald in His Own Time (1971), 404-9; and D. G. Kehl, "Thalia Does the Charleston: Humor in the Fiction of F. Scott Fitzgerald," F. Scott Fitzgerald in the Twenty-First Century (2003): 202-22.

13. Yeats made this comment to Compton Mackenzie-the founder of Gramophone magazine-who repeated it several years later in a memoir. See My Record of Music (1955), 53. Mackenzie, as it happens, was one of Fitzgerald's first literary idols, with his novel Sinister Street (1913-1914) - the tale of a young man's personal and intellectual development at Oxford University-frequently named as a major influence on This Side of Paradise.

14. Conrad, like Pater, also declared music to be the highest of the arts; see his "Preface" to The Nigger of the "Narcissus." For Fitzgerald's acknowledgement of Conrad's influence, see his "Introduction to The Great Gatsby" (1934), Rpt. in F. Scott Fitzgerald In His Own Time: A Miscellany (1971).

\section{Works Cited}

Barthes, Roland. S/Z: An Essay. Trans. Richard Miller. New York: Hill and Wang, 1970.

Breitwieser, Mitchell. "Jazz Fractures:

F. Scott Fitzgerald and Epochal Representation." American Literary History 12.3 (2000): 359-81.
Bromell, Nicholas Knowles. Tomorrow Never Knows: Rock and Psychedelics in the 1960s. Chicago: U of Chicago P, 2000.

Bruccoli Matthew J., ed. New Essays on The Great Gatsby. Cambridge: Cambridge UP, 1985. 
Bull, Michael. Sounding out the City: Personal Stereos and the Management of Everyday Life. New York: Berg, 2000.

Caryll, Ivan, and C. M. S. McLellan. My Beautiful Lady. New York: Chappell \& Co., Ltd., 1911. "My Beautiful Lady." Perf.

Elizabeth Spencer. Edison, 1911

$<$ http://cylinders.library.ucsb.edu $>$.

Chion, Michel. Audio-Vision: Sound on Screen. 1990. Trans.

Claudia Gorbman. Rpt. New York:

Columbia UP, 1994.

Conrad, Joseph. The Nigger of the "Narcissus." 1897. Rpt. New York: Dover, 1999.

Doctorow, E. L. Ragtime. 1975. Rpt. New York: Modern Library, 1997.

Dos Passos, John. The Best Times: An Informal Memoir. New York: The New American Library, 1966.

Dreiser, Theodore. An American Tragedy. 1925. Rpt. New York: Dell, 1959.

Eisenstein, Sergei. Film Form: Essays in Film Theory. Trans. Jay Leyda. New York: Harcourt, Brace \& World, Inc., 1949.

Eliot, T. S. The Complete Poems and Plays, 1909-1950. New York:

Harcourt Brace \& Company, 1980.

Emerson, Ralph Waldo. Essays and Lectures. Ed. Joel Porte. New York: Library of America, 1983.

Fitzgerald, Zelda. Save Me the Waltz. 1932. Carbondale: Southern Illinois UP, 1967.
Fitzgerald, F. Scott. The Basil and Josephine Stories. Ed. Jackson R Bryer and John Kuehl. New York: Charles Scribner's Sons, 1973. This Side of Paradise. 1920.

Ed. James L. W. West III. Cambridge: Cambridge UP, 1995.

Fitzgerald, Scott F. The Beautiful and Damned. 1922. Ed. James L. W. West III. Rpt. Cambridge: Cambridge UP, 2008.

- The Great Gatsby. 1925. Ed.

Matthew J Bruccoli. Cambridge:

Cambridge UP, 1991.

- The Love of the Last Tycoon:

A Western. 1941. Ed. Matthew

J Bruccoli. Cambridge: Cambridge UP, 1993.

- F. Scott Fitzgerald in His

Own Time: A Miscellany. Ed. Matthew J Bruccoli and Jackson R. Bryer.

New York: Popular Library, 1971.

- F. Scott Fitzgerald: A Life in

Letters. Ed. Matthew J Bruccoli.

New York: Scribner's, 1994.

- My Lost City: Personal

Essays, 1920-1940. Ed. James L. W. West III. Cambridge: Cambridge UP, 2005.

The Lost Decade: Short

Stories from Esquire, 1936-1941. Ed. James L. W. West III. Cambridge: Cambridge UP, 2008.

Hubbell, Raymond and John L Golden. Poor Butterfly. New York: T. B. Harms \& Francis, Day \& Hunter, 1916. "Poor Butterfly." Perf. Elizabeth Spencer. Edison, 1917 $<$ http://cylinders.library.ucsb.edu $>$. 
Jerving, Ryan. "Early Jazz Literature (And Why You Didn't Know)."

American Literary History 16.4 (2004): 648-74.

Kenner, Hugh. A Homemade World: The American Modernist Writers. Baltimore: Johns Hopkins UP, 1989.

Kittler, Friedrich A. Gramophone, Film, Typewriter. 1986. Trans.

Geoffrey Winthrop-Young and Michael Wutz. Stanford: Stanford UP, 1999.

Lastra, James. Sound Technology and the American Cinema: Perception, Representation, Modernity. New York: Columbia UP, 2000.

Lewis, Sinclair. Main Street. 1920. Rpt. New York: Library of America, 1992.

Mackenzie, Compton. My Record of Music. London: Hutchinson, 1955.

Nathan, George Jean. Another Book on the Theatre. New York: B.W.

Heuebsch, 1915.

Powers, Richard. The Time of Our Singing. New York: Picador, 2003.
Prigozy, Ruth. “'Poor Butterfly':

F. Scott Fitzgerald and Popular

Music." Prospects 2 (1976): 41-68.

Robledo, Julian and Dorothy Terriss.

Three O'clock in the Morning.

London: West's Limited, 1921.

"Three O'clock in The

Morning." Perf. John McCormack.

Victrola, $1922<$ http://www.archive. org $>$.

Schwartz, Jean and Jerome William.

Ring, Ting-A-Ling. New York: Jerome \& Schwartz, 1912.

_ . "Ring, Ting-A-Ling." Perf.

Ada Jones. Columbia, $1912<$ http://

www.archive.org $>$.

Seldes, Gilbert. The Seven Lively Arts.

New York: Harper \& Brothers, 1924.

Small, Christopher. Musicking: The

Meanings of Performing and Listening.

Hanover: Wesleyan UP, 1998.

Stern, Milton R. The Golden Moment: The Novels of F. Scott Fitzgerald.

Urbana: U of Illinois P, 1970.

Wojcik, Pamela Robertson and Arthur Knight, eds. Soundtrack Available: Essays on Film and Popular Music. Durham: Duke UP, 2001. 